\title{
Small RNAs regulate plant responses to filamentous pathogens
}

Tung Kuan ${ }^{1,2, *}$, Yi Zhai ${ }^{1,2, *}$, Wenbo Ma ${ }^{1,2, \#}$

\section{Abstract}

Small RNAs are central players of RNA silencing in eukaryotes. These short RNA molecules (20-25 nucleotides in length) repress target gene expression based on sequence complementarity. While small RNAs are well-known for their essential function in regulating growth and development, recent research has revealed that they also influence plant immunity. Extensive changes in small RNA accumulation have been observed during infection. This review focuses on specific small RNA changes that are involved in plant responses to filamentous eukaryotic pathogens including fungi and oomycetes. We describe how changes in small RNA accumulation influence plant immunity and summarize the cellular processes affected by these small RNAs. In particular, we discuss secondary small interfering RNAs that directly modulate the expression of defense-related genes.

\section{Introduction}

Constantly challenged by potential microbial pathogens in the surrounding environment, plants have evolved two branches of immunity to prevent infection [1, 2]. The first branch relies on the recognition of microbial- or pathogen-associated molecular patterns (MAMPS or PAMPs) by transmembrane proteins called the pattern recognition receptors (PRRs) [3]. Activation of PRRs leads to defense responses, including reactive oxygen species (ROS) production, cell wall reinforcement (callose deposition) and antimicrobial compound secretion. This pattern-triggered immunity (PTI) serves as a general or basal defense that prevents the colonization of the 
majority of potential pathogens; however, successful pathogens are able to effectively defeat PTI through the function of effectors. It became clear that effectors are produced by a broad range of plant pathogens and their major function is to suppress host immunity [4]. As a counteractive strategy, plants evolved another layer of defense, which depends on the recognition of specific pathogen effectors by resistance $(R)$ proteins in a gene-for-gene manner [5]. Canonical R proteins share conserved nucleotide-binding leucine-rich repeat (NB-LRR) domains, and the activation of the NB-LRR proteins results in effector-triggered immunity (ETI). ETI often involves programmed cell death called the hypersensitive response $(\mathrm{HR})$, which restricts the spread of the pathogen from initial infection sites [2].

Both $\mathrm{PTI}$ and ETI involve defense signal transduction through kinases (such as mitogenactivated protein kinases or MAP kinases) and extensive transcriptional reprogramming, which eventually leads to immunity [6]. This process requires precise regulation due to its high energy consumption that inevitably affects plant growth $[7,8]$. There is an accumulating body of evidence suggesting that small non-coding RNAs are integral regulators of defense-related gene expression during pathogen infection as well as a pivotal switch that governs the growth/defense tradeoff [9-11].

Small RNA silencing is a universal and fundamental gene regulation mechanism in eukaryotes that governs cellular processes. In plant immunity, it is well-established that virus-induced RNA silencing is critical for anti-viral defense $[12,13]$. More recent studies showed that specific small RNAs were differentially accumulated during infection by bacteria, fungal and oomycete pathogens $[10,14]$. Small RNAs have also been found to suppress PTI and ETI in the absence of pathogens to avoid autoimmune responses $[15,16]$. Furthermore, effectors with small RNA silencing suppression activity have been identified from bacteria [17] and oomycetes [18, 19]. These findings strongly suggest that small RNA silencing is required to establish effective defense response to a large variety of pathogens.

Plant pathogens are generally divided into biotrophs and necrotrophs based on their infection styles. Biotrophic pathogens establish a complex symbiosis relationship with specific hosts and feed on living tissues; on the contrary, necrotrophic pathogens kill plant cells and obtain nutrients from dead/collapsed tissues of a broad range of hosts [20]. Responding to these different infection strategies, plants utilize distinctive defense mechanisms [20, 21]. In this review, we will focus on biotrophic and hemi-biotrophic (containing an early biotrophic infection stage and a late necrotrophic infection stage) pathogens due to their complex molecular interactions with the hosts. Furthermore, we will focus on the filamentous eukaryotic pathogens as there is emerging body of evidence that suggest a particularly important role of small RNAs during plant defense against these destructive pathogens, including fungi and oomycetes.

\section{Evidence suggesting small RNA silencing influences plant immunity}




\subsection{Plant mutants defective in small RNA silencing exhibited altered susceptibility}

Plants produce two major classes of endogenous small RNAs, namely microRNAs (miRNAs) and small interfering RNAs (siRNAs) [11]. miRNAs mediate sequence-dependent posttranscriptional gene silencing (PTGS) by guiding mRNA cleavage and/or translation inhibition; whereas siRNAs can also mediate transcriptional gene silencing (TGS) through sequencedependent DNA modification in addition to PTGS [9, 22]. The core components of plant small RNA silencing pathways include Dicer-like ribonucleases (DCLs) that produce small RNAs from double stranded precursors, Argonaute (AGO) proteins that form the RNA silencing effector complexes, RNA-dependent RNA polymerases (RDRs) that synthesize the double stranded precursors, and double-stranded RNA binding proteins (DRBs) that facilitate small RNA biogenesis [11]. Genes encoding these core components have been characterized for their effect on plant defense during pathogen infection.

\subsection{1 miRNA pathway}

miRNAs, mainly 21 nucleotides in length, are produced from endogenous MIR loci, where nonprotein coding transcripts are transcribed by RNA polymerase II and form foldback precursors $[11,23]$. The primary miRNA transcripts (pri-miRNAs) are processed by Dicer-like 1 (DCL1) to generate double-stranded miRNA duplexes in the nucleus. These miRNA duplexes are stabilized by HEN1 methyltransferase and exported into cytoplasm where one strand of the duplex is incorporated into AGOs [11, 23]. In plants, most miRNAs are associated with AGO1 (Fig. 1A).

Several plant mutants that are defective in the miRNA pathway showed altered susceptibility upon infection of filamentous pathogens. For example, silencing of OsDCL1 in rice led to enhanced resistance to the blast fungus Magnaporthe oryzae [24]. On the contrary, two dcl1 mutants in Arabidopsis thaliana were hypersusceptible to the oomycete pathogen Phytophthora capsici [19]. These variable phenotypes could be due to the significant changes in plant morphology caused by DCL1 mutations, which may exert different effects on individual interactions between specific pathogens and the hosts. In addition to DCL1, mutations in AGO1 and HEN1 in rice also led to altered resistance to Verticillium dahliae and Verticillium longisporum $[25,26]$. Since AGO1 and HEN1 are involved in both miRNA and siRNA pathways, these phenotypes are more complicated to interprete. Nonetheless, these observations indicate that the miRNA pathway may contribute to the regulation of plant immunity.

\subsection{2 siRNA pathway}

Distinct from miRNAs, siRNAs are derived from invading nucleic acids such as viruses and transgenes, and endogenous loci such as repeats, transposable elements, and genes [11]. 
Typically, the precursors of siRNAs are long double-stranded RNAs synthesized by RDRs facilitated by Suppressor of Gene Silencing 3 (SGS3); and three DCLs in Arabidopsis catalyze the formation of 21-nucleotide (DCL4), 22-nucleotide (DCL2), and 24-nucleotide (DCL3) siRNAs. The 21-nt and 22-nt siRNAs guide gene silencing by PTGS; whereas the 24-nt siRNAs lead to TGS through the RNA-directed DNA methylation (RdDM) pathway [14, 22].

siRNA-mediated PTGS has been implicated in plant immunity during the infection of filamentous pathogens [27]. For example, upon the infection with M. oryzae, expression of OsRDR6 and OsSGS3 was highly induced in a resistant cultivar of rice while such induction was not observed in a susceptible cultivar [28]. A similar induction of $R D R 1$ and $R D R 6$ was also observed in Nicotiana glutinosa during the infection of the oomycete pathogen Phytophthora parasitica and the fungal pathogen Colletotrichum nicotianae [29, 30]. These results indicate RDR6-dependent siRNAs are positive regulators of anti-fungal defense. Indeed, Arabidopsis mutants rdr6, sgs3 and $d c / 4$ were all hypersusceptible to $V$. dahlia [26]. Moreover, an OsRDR6 mutant, called shl2rol, exhibited larger necrotic lesions after infection with $M$. oryzae [28]. These findings indicate siRNAs play a particularly important role in plant defense against filamentous pathogens.

\subsection{Suppression of the host RNAi pathway by pathogen-delivered effectors promotes infection}

As described in the Zigzag model [1], plant hosts and pathogens are engaged in an arms race between plant defense mechanisms and pathogen effector functions. Since small RNA silencing contributes to plant immunity, it is not surprising that pathogens have evolved effectors to interfere with this process for the benefit of infection [12].

The best studied pathogen suppressors of host RNA silencing are viral RNA silencing suppressors (VSRs), which are essential for viral infection [12]. Recently, effectors with RNA silencing suppression activity were also identified from the oomycete pathogens in the genus Phytophthora [18, 31]. Expression of these $\underline{P}$ hytophthora suppressors of $\underline{\mathbf{R} N A}$ silencing (PSRs) promote Phytophthora infection in Arabidopsis, soybean and Nicotiana benthamiana [18, 19, 31]. Further analysis demonstrated that PSR1 affected the biogenesis of both miRNAs and siRNAs by associating with a putative RNA helicase called PINP1, which is involved in the assembly of DCL complexes for small RNA processing. Silencing of PINP1 in Arabidopsis and N. benthamiana led to enhanced susceptibility to Phytophthora capsici and Phytophthora infestans, respectively, confirming that an intact small RNA pathway is required to establish effective immunity against Phytophthora infection [19]. Different from PSR1, PSR2 specifically affected the accumulation of siRNAs in Arabidopsis; nonetheless, PSR2-expressing Arabidopsis plants were drastically more susceptible to $P$. capsici [31]. The identification of RNA silencing suppressors in filamentous pathogens strongly support the idea that the plant small RNA silencing pathway as an integral component of the immune system and a conserved target of 


\section{Unveiled roles of small RNAs in plant-fungus/oomycete interactions}

A key step towards understanding how small RNA silencing regulates plant immunity is to identify specific small RNAs that affect plant defense responses and characterize their function, as well as the function of their target genes, during pathogen infection. Over the years, genomewide small RNA analyses using microarray and small RNA sequencing have been conducted for several plant-filamentous pathogen interactions. Recent advances in next-generation sequencing have allowed the rapid identification of pathogen-responsive small RNAs and their predicted target genes. Most of these studies looked for differentially accumulated small RNAs upon pathogen infection or pathogen elicitor (i.e. PAMP) treatment; other studies compared small RNA profiles in susceptible vs. resistant plant cultivars or between plants infected by pathogen strains with different levels of virulence. In addition, some small RNA profiling studies were supported with degradome sequencing data for genome-wide analysis of small RNA target genes. Here, we summarize the main findings from these studies with a focus on the specific cellular processes affected by small RNAs during infection and discuss how small RNAs may modulate defense responses.

\section{1 miRNAs}

After the pioneer miRNAs profiling in loblolly pine (Pinus taeda) upon fusiform rust infection [32], more than 40 genome-wide miRNA studies have been reported in Arabidopsis and other crop species, including rice, wheat, soybean, tomato, eggplant, oilseed rape, cotton, poplar and cucumber. Together, changes in more than 100 miRNAs were found in response to one or more of the following filamentous pathogens: Bipolaris sorokiniana [33], Blumeria graminis f. sp. tritici [34], Botryosphaeria dothidea [35], Cronartium quercuum f. sp. fusiforme [32], Dothiorella gregaria [36], Fusarium culmorum [33], Fusarium virguliforme [37], Fusarium oxysporum [38-40], Hyaloperonospera arabidopsidis [41], Magnaporthe oryzae [24, 42-44], Melampsora laricipopulina [45], Phakopsora pachyrhizi [46], Puccinia graminis f. sp. tritici [47], Puccinia striiformis f. sp. tritici [48-52], Verticillium dahliae [53, 54], Verticillium longisporum [25], Phytophthora infestans [55], Phytophthora sojae [56-58], Pseudoperonospora cubensis [59] as well as the myxomycete parasite Plasmodiophora brassicae [60]. A summary of these miRNA profiling studies is shown in Table $\mathbf{1}$ and $\mathbf{2}$, which serve as an overview of miRNAs that are differentially accumulated in various pathosystems.

Based on their predicted targets, pathogen-responsive miRNAs are classified into two categories: 1) growth-regulating miRNAs that indirectly affect immunity (summarized in Table 1); and 2) defense-regulating miRNAs that directly affect immunity (summarized in Table 2). Enhanced plant resistance is often found to correlate with up-regulation of growth-regulating 
miRNAs (such as miR159, miR160, miR162, miR164, miR168 and miR393) and downregulation of defense-regulating miRNAs (such as miR390, miR408, miR482, miR827, miR869). Plant defense and growth are believed to be antagonistic processes: upon perception of potential pathogens, plants prioritize immune response over growth [8]. Pathogen-responsive miRNAs may act as fine tuners to control the defense/growth tradeoff [8, 61]. Below, we discuss three cellular processes influenced by pathogen-responsive miRNAs, i.e. phytohormone signaling, defense response, and RNA silencing to provide insights into how miRNAs regulate plant immunity. Mechanisms by which pathogen-responsive miRNAs are regulated during infection are also discussed.

\subsubsection{Pathogen-responsive miRNAs regulate phytohormone signaling}

Phytohormones are important signaling molecules that have profound impact on plant growth, development, and stress responses. Target analyses revealed that pathogen-responsive miRNAs may exert their functions through regulating various phytohormone signaling pathways, thereby altering plant immunity. In this section, we discuss how pathogen-responsive miRNAs regulate auxin, salicylic acid (SA), jasmonic acid (JA), and ethylene (ET) signaling and the crosstalk among the hormonal network.

As a major growth hormone with pleiotropic effect on plant development, auxin signaling has an antagonistic interaction with SA-mediated defense pathway against biotrophic pathogens [8]. Several miRNAs known to regulate auxin signaling are conserved in plants. Since reduction of auxin response leads to the activation of SA signaling, auxin-repressing miRNAs could activate resistance. For example, the auxin receptor transport inhibitor response 1/auxin-related $F$ box (TIR1/AFB) is targeted by miR393, which is found to accumulate to higher levels during the infection of several plants by various pathogens [34, 36, 41, 57]. Importantly, knocking down miR393 in soybean using the short target tandem mimic (STTM) approach led to hypersusceptibility to the oomycete pathogen Phytophthora sojae, suggesting that miR393 is a positive regulator of plant defense [57]. Moreover, PAMP treatment resulted in increased accumulation of miR393 $[57,62]$, supporting that up-regulation of miR393 is a general plant response to establish PTI. In addition to miR393, several other auxin-regulating miRNAs, such as miR160, miR164 and miR167, were also found to be up-regulated in response to filamentous pathogens. miR160 and miR167 regulate the auxin response factors (ARFs), which are transcription factors inducing downstream auxin-responsive gene expression [35, 44, 60]; and miR164 regulates NAM/ATAF/CUC (NAC) transcription factors, which activate the expression of the auxin receptor TIR/AFB [35, 36, 44, 48, 59]. Increased levels of these miRNAs repress auxin signaling by targeting multiple key components in the pathway and achieve a switch from growth to immune response. 
SA, JA, and ET are three major defense hormones in plants. SA plays a central role in defense against biotrophic and hemibiotrophic pathogens, although all three synergistically contribute to defense against various pathogens [20]. Extensive crosstalk has been found between SA, JA, and ET signaling pathways, which is essential for proper integration of immune responses [61]. Using combination of miRNA profiling and degradome analysis, a recent study revealed a comprehensive list of miRNA/target interaction pairs in rice that were responsive to PAMP treatment of Magnaporthe oryzae [42]. Some of these miRNAs potentially target genes involving in the biogenesis and/or metabolism of SA, JA and ET. For example, miR5512 regulates a gene encoding the SAM:SA carboxyl methyltransferase (SAMT), which converts SA into a biologically inactive form methyl SA. In addition, miR1428 targets the gene encoding JA carboxyl methyltransferase (JMT), an enzyme that converts JA into methyl JA. Finally, miR1846 targets ACC oxidase (ACO), a key enzyme in ET biosynthesis by converting the immediate precursor 1aminocyclopropane-1-carboxylic acid (ACC) to ET [42]. Although the exact roles of these miRNA/target pairs during pathogen infection remain to be examined, changes in these miRNAs could potentially alter the defense hormone signaling, and thereby affecting immunity.

\subsubsection{Pathogen-responsive miRNAs regulate defense signaling}

Plant immunity is initiated following recognition of pathogen-derived ligands including peptides and carbohydrates by membrane-bound pattern recognition receptors or pathogen cytoplasmic effectors by intracellular receptors, which are mainly NB-LRR proteins. Following defense signal transduction, diverse immune responses are activated as a result of transcriptional reprogramming. In this section, we discuss how pathogen-responsive miRNAs might regulate each of these steps during the establishment of plant immunity.

\subsubsection{Pathogen perception}

Pattern recognition receptors have been reported to be targets of miRNAs. For example, miR390 and miR827 were predicted to target receptor-like protein kinases (RLKs) in crop species [25, 43]. miR390 was found to be down-regulated during the infection of Verticillium longisporum in oilseed rape. One of the predicted targets of miR390 is a RLK that contains the Leucine-rich repeat domain [25, 43]. Reduced accumulation of miR390 following fungal infection could lead to increased expression of this RLK, which may enhance pathogen recognition signaling. A similar observation was also made for miR827, which targets a wall-associated RLK (WAK) in rice $[43,44]$. Decreased accumulation of miR827 in rice after the infection of Magnaporthe oryzae could lead to higher expression levels of the WAK [43, 44]. Another class of transmembrane receptors that could also be regulated by miRNAs is lectins [42]. miR1439 in rice is predicted to target mannose-binding lectins, which may perceive pathogen attachment and subsequently activate defense response [42]. 
Intracellular NB-LRR receptors can also be regulated by pathogen-responsive miRNAs. In particular, miRNAs are considered to be master regulators of $N B$ - LRR genes, especially in legumes [64]. Since miRNA-mediated post-transcriptional regulation of $N B$-LRR genes often involves the production of secondary siRNAs, we will discuss this regulation in detail in the siRNA section below.

\subsubsection{Oxidative stress}

Pathogen recognition leads to rapid accumulation of reactive oxygen species (ROS), which is thought to directly attenuate the pathogens and also serves as a defense signal [65]. Associated with changes of extracellular $\mathrm{pH}$, membrane potential, ion fluxes, protein phosphorylation patterns and cytosolic $\mathrm{Ca}^{2+}$ levels, ROS induces anti-microbial responses including programmed cell death, callose deposition, and systemic resistance [65]. Several pathogen-responsive miRNAs are predicted to target peroxidases, which may participate in the metabolism of ROS. For example, miR5783 targets peroxiredoxin in wheat infected with Fusarium culmorum [33]; and miR159 targets peroxidases in poplar during the infection by stem canker fungus Botryosphaeria dothidea [35]. Furthermore, a novel soybean miRNA, miR-Seq11, showed decreased accumulation following infection by the rust fungus Phakopsora pachyrhizi; miRSeq11 can presumably affect ROS production by regulating peroxidase activity [46].

Enzymes involved in ROS detoxification, such as superoxide dismutase (SOD), ascorbate oxidase, glutaredoxin, and glyoxalase, are important for maintaining a dynamic balance of ROS levels in plants to prevent tissue damage. These enzymes are also among the targets of pathogen-responsive miRNAs [33, 35, 39, 42, 44]. The best-studied miRNA/target pair in regulating ROS levels was reported from the rice- $M$. oryzae pathosystem [44]. miR398 regulates a $\mathrm{Cu} / \mathrm{Zn}$ superoxide dismutase (CSD), which is an important enzyme for ROS detoxification. During M. oryzae infection, miR398 was up-regulated; and the subsequent decrease in CSD abundance led to increased ROS accumulation. Consistently, overexpression of MIR398 resulted in enhanced resistance against $M$. oryzae [44].

\subsubsection{Defense responses}

To fight off invading filamentous pathogens, plants develop various defense strategies such as reinforcing structural barriers, synthesizing secondary metabolites, and producing anti-microbial enzymes and proteins. These basal defense responses are modulated by several pathogenresponsive miRNAs. For example, lignin is the primary composition of cell walls, and lignified cell walls are more resistant to pathogen invasion [65]. In wheat infected with Puccinia species, the accumulation of miR408 was decreased, probably leading to the activation of its target plantacyanin and enhancing lignin formation [47, 52]. To facilitate anti-microbial compound production, miR393 was up-regulated in soybean roots infected with the oomycete Phytophthora 
sojae [57]. Increased miR393 activates the production of isoflavonoids, the major phytoalexins of soybean, probably through re-directing the secondary metabolism of plants towards synthesizing compounds against biotrophic pathogens [41].

Pathogen-responsive miRNAs also regulate the production of anti-microbial enzymes. In rice, infection of $M$. oryzae led to differential accumulation of miR426, which regulates the expression of chitinase, the hydrolysis enzyme for fungal cell wall degradation [42]. In soybean, miR397 regulates the expression of laccases, a family of enzymes conferring resistance against the sudden death syndrome caused by Fusarium virguliforme [37, 46]. Wheat miR869 was found to be down-regulated in response to the fungal pathogens $F$. culmorum and $B$. sarokiniana. miR869 targets the pathogenesis-related factor glucuronosyltransferase, a defensive enzyme known to act against mycotoxins secreted by Fusarium species [33]. Another novel miRNA of wheat, PC-490, was also down-regulated during infection by the rust fungus Puccinia striiformis. PC-490 represses the expression of a RabGAP/TBC domain-containing protein, which contributes to wheat resistance to Puccinia rust by regulating GTP hydrolysis [49].

Several miRNAs with increased accumulation during the infection of filamentous pathogens were found to contribute to resistance by repressing the expression of immune suppressors. For example, the up-regulation of miR1432 in wheat during the infection of $P$. striiformis may lead to reduced expression of calcium ion-binding protein, a negative regulator of plant immunity, thereby enhancing resistance to stripe rust [50]. The ubiquitin receptor, ubiquillin, another negative regulator of wheat immunity, could also be repressed by a novel miRNA PC-7484, which was enriched during $P$. striiformis infection [50].

\subsubsection{Pathogen-responsive miRNAs in RNA silencing pathways}

miRNA species that target the transcripts of core components of small RNA silencing are often found to be differentially accumulated in plants during pathogen infection. These miRNAs include miR162 (targeting DCL1) that regulates the miRNA pathway, miR168 (targeting AGO1) that regulates both miRNA and siRNA pathways, and miR818 (targeting RDR2), miR1847 (targeting AGO4), and miR823 (targeting Chromomethylase 3, CMT3) that regulate the RdDM pathway [24, 38, 39, 42, 50]. In most cases, these miRNAs were up-regulated during infection. miR168 is one of the most frequently observed pathogen-responsive miRNAs and found to be induced in rice, oilseed rape, Arabidopsis, soybean and poplar during the infection of a large variety of fungal and oomycete pathogens [24, 25, 35, 36, 38, 42-44, 57]. Detailed analysis of how miR168 represses its target transcript $A G 01$ revealed a feedback regulation loop between miR168 and AGO1: increased miR168 levels lead to a constant decline in AGO1 accumulation, thereby limiting its own function in suppressing AGO1 expression [38]. It was proposed that this feedback loop provides a fine adjustment on the AGO1 levels and contributes to the flexibility of RNA silencing systems under rapidly-changing environmental conditions (Fig. 2). The specific 
function of miR168, as well as other miRNAs that regulate core small RNA silencing components, should be carefully characterized in order to understand how they affect plant immunity.

\subsubsection{Transcriptional regulation of MIR genes during infection}

The differential accumulation of miRNAs during pathogen infection is usually accompanied by the differential expression of the corresponding MIR genes, suggesting that pathogenresponsive miRNA changes are due to transcriptional regulation. Further analyses in poplar challenged with the stem canker fungus Botryosphaeria dothidea [35] and in Arabidopsis challenged with Fusarium oxysporum [38] revealed two groups of cis-regulatory elements in MIR promoters. The first group includes stress-responsive elements such as the ABA-responsive elements (ABREs), anaerobic induction elements (AREs), heat-stress response elements (HSEs), low temperature-response elements (LTRs), MYB-binding site (MBS), defenseresponsive TC-rich repeats, and fungal-responsive W1-box elements. The second group includes phytohormone-responsive elements including methyl JA-responsive, ET-responsive (EREs), GA-responsive (GARE), and the P-box elements [35]. Therefore, the expression of MIR genes is likely under the control of stress- and phytohormone-related transcription factors (TFs) during pathogen infection. Interestingly, many target genes of pathogen-responsive miRNAs encode stress- and phytohormone-related TFs, forming feedback regulation networks that are important for fine-tuning plant response during infection through small RNAs (Fig. 2). These miRNA-TF pairs include miR156-SPL, miR159-MYB, miR160-ARF, miR164-NAC, and miR167ARF.

\section{2 siRNA}

Although not as well studied as miRNAs, emerging evidence suggests that siRNAs are also important regulators of plant immunity. Upon filamentous pathogen infection, extensive changes in siRNAs have been observed from several pathosystems [32, 38, 54, 57-59]. Many pathogenresponsive siRNAs are 24-nt in length and derived from repeat sequences or transposons [34, 58]. These changes are usually found to be broadly distributed throughout the genome, and thereby representing a general response that affects transposon activities under stress conditions $[32,38,59,66]$.

A specific class of siRNAs that has appeared to be particularly important for plant defense against fungal and oomycete pathogens is secondary siRNAs derived from transcripts targeted by specific miRNAs (Fig. 1B). In this case, miRNA-mediated cleavage leads to the synthesis of long dsRNAs by RDR6 and SGS3 [22]. These dsRNA precursors are then processed to produce secondary siRNAs. Depending on the dicing enzyme, the length of secondary siRNAs can be 21-nt, 22-nt or 24-nt. The 21-nt secondary siRNAs act like miRNAs and repress target gene 
expression in trans or in cis through PTGS. Arabidopsis mutants rdr6 and sgs3, which are

352

353

354

355

356

357

358

359

360

361

362

363

364

365

366

367

368

369

370

371

372

373

374

375

376

377

378

379

380 defective in secondary siRNA production showed compromised resistance to the fungal pathogens Verticillium dahlia [26]; a rice rdr6 mutant was also more susceptible to Magnaporthe oryzae [28]. In addition, the Phytophthora RNA silencing suppressor PSR2 specifically interferes with the accumulation of secondary siRNAs in Arabidopsis to promote infection [18, 31]. These findings suggest that the secondary siRNA pathway is required for plant immunity. On the contrary, mutations in Arabidopsis RDR6 either exhibited unchanged resistance [17] or enhanced resistance to the bacterial pathogen Pseudomonas syringae [13]. Taken together, secondary siRNAs seem to be particularly important for plant response to filamentous pathogens.

\subsubsection{Phased siRNAs (phasiRNAs) regulate NB-LRR genes}

Most secondary siRNAs are in phase with the miRNA cleavage site; therefore, they are named phased siRNAs or phasiRNAs [14, 22, 67]. Differential accumulation has been observed in phasiRNAs during infection. For example, levels of phasiRNAs were found to be reduced in cotton roots inoculated with $V$. dahlia [54]. In addition, miRNAs that can trigger phasiRNA production were also down-regulated in loblolly pine infected with the rust fungus Cronartium quercuum f. sp. fusiforme [32]. The best-known class of genes that is targeted by miRNAs and producing phasiRNAs is $N B-L R R$, which encodes resistance proteins essential for $\mathrm{ETI}[67,68]$. NB-LRR proteins can be further classified into toll interleukin 1 receptor (TIR-NB-LRRs, TNLs) and coiled-coil (CC-NB-LRRs, CNLs) based on their distinctive N-terminal motifs [69]. Genes encoding TNLs or CNLs have both been found to be targeted by miRNAs and serve as " $P H A S$ " loci to produce phasiRNAs, which subsequently silence additional NB-LRR genes in trans or in cis $[64,68,70]$. For example, the conserved miR482 superfamily binds to sequences within the $N B$-LRR genes that encode the highly conserved P-loop motif; therefore, phasiRNAs produced from the miR482-targeted $N B$ - $L R R$ genes are presumably able to repress an amplified number of $N B-L R R$ genes $[68,71,72]$. In this manner, repression of a large number of $N B-L R R$ genes can be accomplished by a few miRNAs through the production of phasiRNAs. The best example of this mechanism has been shown in legumes, where three 22-nt miRNA families act as master regulators for $N B-L R R$ gene expression [64].

Not all studies on phasiRNA-triggering miRNAs looked at the associated phasiRNAs during pathogen infection; nonetheless, some of these miRNAs affect plant resistance to a large variety of pathogens including viruses, bacteria, fungi and oomycetes, indicating that they regulate multiple $N B-L R R s$, possibly through triggering phasiRNA production [68, 70-72]. More recently, evidence suggesting phasiRNA-mediated regulation of $N B-L R R$ genes during infection of filamentous pathogens has emerged. A summary of these miRNA families is shown in Table 2. 
As negative regulators of $N B$-LRRs, phasiRNA-producing miRNAs are presumably downregulated upon infection to enhance ETI [67]. Consistent with this assumption, decreased levels of miRNAs belonging to the miR482 family have been found in soybean infected with the oomycete pathogen P. sojae [56] and the fungal pathogen Phakopsora pachyrhizi [46], in cotton infected with the fungal pathogen Verticillium dahliae [73], as well as in tomato infected with the oomycete pathogen $P$. infestans [55] and the fungal pathogen Fusarium oxysporum [39]. Concomitant with the reduced parental miRNA levels, a reduction in the accumulation of phasiRNAs and the corresponding induction of $N B$-LRR genes was also observed in $P$. sojaeinfected soybean [58]. As such, suppression of phasiRNA production during pathogen infection could de-repress NB-LRR gene expression to enhance resistance. However, other studies suggested the opposite pattern. For example, the abundance of miR1507 and miR2109, together with their associated phasiRNAs was increased during the early infection stage of $P$. sojae in soybean; consistently, the expression of their targeted $N B$-LRR genes was repressed [57]. Similarly, the transcript levels of MIR9863 and the abundance of miR9863-derived phasiRNAs were also increased in barley infected with the powdery mildew fungal pathogen Blumeria graminis $f$. sp. hordei (Bgh). miR9863 family members regulate the $C N L$ gene Mla (Mildew resistance locus a), which confers resistance to $B g h$ [74]. These results indicate that phasiRNA changes are dynamic during pathogen infection. This is not surprising because precise regulation of $N B-L R R$ genes is essential to minimize tissue damage and other fitness costs. Changes in phasiRNA accumulation could be affected by specific pathosystems used in specific studies, especially differences in the levels of susceptibility and infection stages. Indeed, down-regulation of miR482 in tomato was only found in a resistant cultivar when infected with the fungal pathogen F. oxysporum [39]. Furthermore, in addition to one miR482 family member that was down-regulated in $P$. infestans-infected tomato (as mentioned above), another member of the same miRNA family was up-regulated [55]. Further investigation on phasiRNA-based NB$L R R$ regulation will be important to understand the mechanism by which the secondary siRNA pathway contributes to plant immunity.

\subsubsection{PhasiRNAs regulate other genes}

Other than NB-LRRs, genes encoding Pentatricopeptide repeat proteins (PPR), MYB transcription factors and other protein families are also known to be targets of miRNAs and their associated phasiRNAs $[58,67,68]$. Similar to $N B$-LRRs, PPR genes form a large family with members that could be targeted by miRNAs for phasiRNA production, which in turn regulate additional gene members [75]. PPRs regulate RNA processing, stability, editing or translation of proteins that exert key functions in mitochondria and chloroplasts. These organelles are important for plant defense by producing ROS and SA [76, 77]. Recently, $23 P P R$ genes were identified as PHAS loci from soybean infected with $P$. sojae [58]. PhasiRNAs derived from $P P R$ loci were increased during the early stage of $P$. sojae infection, leading to reduced expression of 
multiple $P P R$ genes [57]. Intriguingly, the expression levels of some phasiRNA-targeting PPR genes were significantly higher in a susceptible cultivar during $P$. sojae infection, suggesting a possible correlation between PPRs and plant immunity [57].

Although phasiRNAs are believed to be highly effective in regulating large gene families, such as $N B-L R R$ and PPR genes, other targets related to defense have also been found. Two 21-nt miRNA families, sly-, stu-miR6022 and nta-miR6021 that are able to trigger phasiRNA production were predicted to target members of Hcr9 (Homologs of Cladosporium fulvum resistance 9) gene family, which encode membrane-bound proteins with the LRR domain and confer resistance to fungal infection in tomato [70]. Genes involved in small RNA silencing could also be regulated by phasiRNAs. For example, DCL2 acts as a PHAS locus where phasiRNA production is triggered by miR1507 in Medicago truncatula and miR1515 in soybean; and SGS3 could also be targeted by miR2118 for phasiRNA production in soybean [58,64]. As such, phasiRNA biogenesis can be modulated as a feedback loop to achieve precise regulation in response to pathogen infection.

\section{Conclusions and Perspectives}

The recent development of next-generation sequencing has allowed rapid accumulation of small RNA profiling data from various pathosystems, many of which concern destructive filamentous pathogens including fungi and oomycetes. A large variety of small RNAs are found to be differentially accumulated during pathogen infection. Presumably, the small RNA changes lead to differential expression of their target genes, and subsequently influence immune response. miRNAs are well established for their roles in regulating growth and development. Some of these growth-regulating miRNAs are up-regulated at early infection stages and are likely to promote the establishment of immunity by inhibiting growth. As such, miRNAs may facilitate the transition from growth to defense. Other small RNAs could directly target defense-related genes and contribute to immunity. In general, small RNAs that directly downregulate defense-related genes should be down-regulated in order to activate defense responses. However, not all of the pathogen-responsive small RNAs show this pattern. It is important to note that small RNA changes are dynamic during infection, especially given the growth/defense tradeoff. For hemibiotrophic pathogens, small RNA profiles at the early (biotrophic) or late (necrotrophic) infection stages may be drastically different. These factors need to be carefully considered when interpreting the small RNA profiling data.

Although pathogen-responsive small RNAs are presumed to regulate plant defense response, direct evidence of their effect on plant immunity is lacking. Most of the published studies focused on small RNA profiling and target gene prediction, and only a small number confirmed the predicted targets and/or corresponding expression changes of the target genes. Importantly, very few studies actually examined the function of individual small RNA using genetic 
manipulations (e.g. [25, 41, 43, 44, 57]). Indeed, traditional approaches to interrogate gene function using genetic mutants are not easily applicable to small RNA research due to their small size. Transcript precursors of miRNAs are usually 70 to a few hundred nucleotides in length, and many miRNA families are composed of multiple genes that encode mature miRNAs with highly similar sequences and potentially overlapping functions. One technology that could potentially address this challenge is short tandem target mimic (STTM), which sequesters specific small RNAs to inhibit their function [78]. Using STTM and other genetic approaches such as CRISPR, future research on the functional characterization of specific small RNAs will provide mechanistic insight into small RNA-mediated regulation of plant immunity.

Emerging evidence suggests that the secondary siRNA pathway is particularly important for plant defense against filamentous pathogens. Generated from miRNA-targeted transcripts, secondary siRNAs can effectively regulate defense-related genes through an amplification effect. The best studied targets of these secondary siRNAs are NB-LRR genes; however, the PPR gene family has emerged as another major target of secondary siRNAs that can influence immune response. Comprehensive analyses on the function of the secondary siRNA pathway and specific siRNAs (or their parental miRNAs) are required to fully understand how these siRNAs regulate plant immunity.

Finally, current studies only reported endogenous plant genes as predicted targets of pathogenresponsive small RNAs. However, it is intriguing to postulate that plant RNAs may enter pathogen cells and affect pathogen gene expression [27]. This possibility is attractive, especially with the recent discovery of pathogen effectors possessing RNA silencing suppression activity. In-depth investigation of plant small RNAs for target prediction/identification using pathogen genome sequences will advance our understanding of defense-counter defense mechanisms during plant interactions with eukaryotic pathogens.

\section{Acknowledgements}

Research in the Ma laboratory has been supported by the Agriculture and Food Research Initiative competitive grants program, Award \# 2014-67013-21554 from the USDA National Institute of Food and Agriculture, the USDA-RSAP grant \#CA-R-PPA-7699-H, and the US National Science Foundation-Plant Genome Research Program Award \# IOS-1340001. TK is supported by oversea graduate student scholarship from Taiwan Department of Education.

\section{References}

[1] Jones JDG, Dangl JL. The plant immune system. Nature 2006;444:323-9.

[2] Boller T, He SY. Innate immunity in plants: an arms race between pattern recognition receptors in plants and effectors in microbial pathogens. Science 2009;324:742-3.

[3] Monaghan J, Zipfel C. Plant pattern recognition receptor complexes at the plasma membrane. Curr Opin Plant Bio 2012;15:349-57. 
[4] Dou DL, Zhou JM. Phytopathogen Effectors Subverting Host Immunity: Different Foes, Similar Battleground. Cell Host \& Microbe 2012;12:484-95.

[5] Dangl JL, Horvath DM, Staskawicz BJ. Pivoting the plant immune system from dissection to deployment. Science 2013;341:746-51.

[6] Tsuda K, Katagiri F. Comparing signaling mechanisms engaged in pattern-triggered and effectortriggered immunity. Curr Opin Plant Bio 2010;13:459-65.

[7] Denancé N, Sánchez-Vallet A, Goffner D, Molina A. Disease resistance or growth: the role of plant hormones in balancing immune responses and fitness costs. Front Plant Sci 2013;3389-400.

[8] Huot B, Yao J, Montgomery BL, He SY. Growth-defense tradeoffs in plants: a balancing act to optimize fitness. Mol Plant 2014;7:1267-87.

[9] Bologna NG, Voinnet O. The diversity, biogenesis, and activities of endogenous silencing small RNAs in Arabidopsis. Annu Rev Plant Bio 2014;65:473-503.

[10] Staiger D, Korneli C, Lummer M, Navarro L. Emerging role for RNA - based regulation in plant immunity. New Phytol 2013;197:394-404.

[11] Chen XM. Small RNAs and Their Roles in Plant Development. Annu Rev Cell Dev Biol 2009;25:21-44.

[12] Pumplin N, Voinnet O. RNA silencing suppression by plant pathogens: defence, counter-defence and counter-counter-defence. Nat Rev Microbiol 2013;11:745-60.

[13] Cao M, Du P, Wang X, Yu Y-Q, Qu Y-H, Li W, et al. Virus infection triggers widespread silencing of host genes by a distinct class of endogenous siRNAs in Arabidopsis. Proc Natl Acad Sci USA 2014;111:14613-8.

[14] Yang L, Huang $H$. Roles of small RNAs in plant disease resistance. J Integr Plant Biol 2014;56:96270.

[15] Yi H, Richards EJ. A cluster of disease resistance genes in Arabidopsis is coordinately regulated by transcriptional activation and RNA silencing. Plant Cell 2007;19:2929-39.

[16] Boccara M, Sarazin A, Thiebeauld O, Jay F, Voinnet O, Navarro L, et al. The Arabidopsis miR472$R D R 6$ silencing pathway modulates PAMP-and effector-triggered immunity through the posttranscriptional control of disease resistance genes. PLoS Pathog 2014;10:e1003883.

[17] Navarro L, Jay F, Nomura K, He SY, Voinnet O. Suppression of the microRNA pathway by bacterial effector proteins. Science 2008;321:964-7.

[18] Qiao Y, Liu L, Xiong Q, Flores C, Wong J, Shi J, et al. Oomycete pathogens encode RNA silencing suppressors. Nat Genet 2013;45:330-3.

[19] Qiao Y, Shi J, Zhai Y, Hou Y, Ma W. Phytophthora effector targets a novel component of small RNA pathway in plants to promote infection. Proc Natl Acad Sci USA 2015;112:5850-5.

[20] Spoel SH, Johnson JS, Dong X. Regulation of tradeoffs between plant defenses against pathogens with different lifestyles. Proc Natl Acad Sci USA 2007;104:18842-7.

[21] Glazebrook J. Contrasting mechanisms of defense against biotrophic and necrotrophic pathogens. Annu Rev Phytopathol 2005;43:205-27.

[22] Borges F, Martienssen RA. The expanding world of small RNAs in plants. Nat Rev Mol Cell Biol 2015;16:727-41.

[23] Huntzinger E, Izaurralde E. Gene silencing by microRNAs: contributions of translational repression and mRNA decay. Nat Rev Genet 2011;12:99-110.

[24] Zhang D, Liu M, Tang M, Dong B, Wu D, Zhang Z, et al. Repression of microRNA biogenesis by silencing of OsDCL1 activates the basal resistance to Magnaporthe oryzae in rice. Plant Sci 2015;237:2432.

[25] Shen D, Suhrkamp I, Wang Y, Liu S, Menkhaus J, Verreet JA, et al. Identification and characterization of microRNAs in oilseed rape (Brassica napus) responsive to infection with the pathogenic fungus Verticillium longisporum using Brassica AA (Brassica rapa) and CC (Brassica oleracea) as reference genomes. New Phytol 2014;204:577-94.

[26] Ellendorff U, Fradin EF, De Jonge R, Thomma BPHJ. RNA silencing is required for Arabidopsis defence against Verticillium wilt disease. J Exp Bot 2009;60:591-602.

[27] Baulcombe DC. VIGS, HIGS and FIGS: small RNA silencing in the interactions of viruses or filamentous organisms with their plant hosts. Curr Opin Plant Biol 2015;26:141-6.

[28] Wagh SG, Alam MM, Kobayashi K, Yaeno T, Yamaoka N, Toriba T, et al. Analysis of rice RNAdependent RNA polymerase 6 (OsRDR6) gene in response to viral, bacterial and fungal pathogens. J Gen Plant Pathol 2016;82:12-7.

[29] Liu Y, Gao Q, Wu B, Ai T, Guo X. NgRDR1, an RNA-dependent RNA polymerase isolated from Nicotiana glutinosa, was involved in biotic and abiotic stresses. Plant Physio Biochem 2009;47:359-68. [30] Yang H, Wang M, Gao Z, Zhu C, Guo X. Isolation of a novel RNA-dependent RNA polymerase 6 from Nicotiana glutinosa, NgRDR6, and analysis of its response to biotic and abiotic stresses. Mol Bio Rep 2011;38:929-37.

[31] Xiong Q, Ye W, Choi D, Wong J, Qiao Y, Tao K, et al. Phytophthora suppressor of RNA silencing 2 is a conserved RxLR effector that promotes infection in soybean and Arabidopsis thaliana. MPMI 2014;27:1379-89. 
[32] Lu S, Sun YH, Amerson H, Chiang VL. MicroRNAs in loblolly pine (Pinus taeda L.) and their association with fusiform rust gall development. Plant J 2007;51:1077-98. [33] Inal B, Turktas M, Eren H, Ilhan E, Okay S, Atak M, et al. Genome-wide fungal stress responsive miRNA expression in wheat. Planta 2014;240:1287-98. [34] Xin M, Wang Y, Yao Y, Xie C, Peng H, Ni Z, et al. Diverse set of microRNAs are responsive to powdery mildew infection and heat stress in wheat (Triticum aestivum L.). BMC Plant Biol 2010;10:123-33. [35] Zhao JP, Jiang XL, Zhang BY, Su XH. Involvement of microRNA-mediated gene expression regulation in the pathological development of stem canker disease in Populus trichocarpa. PLoS One 2012;7:e44968.

[36] Chen L, Ren Y, Zhang Y, Xu J, Zhang Z, Wang Y. Genome-wide profiling of novel and conserved Populus microRNAs involved in pathogen stress response by deep sequencing. Planta 2012;235:873-83. [37] Radwan O, Liu Y, Clough SJ. Transcriptional analysis of soybean root response to Fusarium virguliforme, the causal agent of sudden death syndrome. MPMI 2011;24:958-72.

[38] Baldrich P, Kakar K, Sire C, Moreno AB, Berger A, Garcia-Chapa M, et al. Small RNA profiling reveals regulation of Arabidopsis miR168 and heterochromatic siRNA415 in response to fungal elicitors. BMC Genomics 2014;15:1083-98.

[39] Ouyang S, Park G, Atamian HS, Han CS, Stajich JE, Kaloshian I, et al. MicroRNAs suppress NB domain genes in tomato that confer resistance to Fusarium oxysporum. PLoS Pathog 2014;10:e1004464. [40] Shapulatov U, Buriev Z, Ulloa M, Saha S, Devor E, Ayubov M, et al. Characterization of Small RNAs and Their Targets from Fusarium oxysporum Infected and Noninfected Cotton Root Tissues. Plant Mol Biol Rep 2015:1-9.

[41] Robert-Seilaniantz A, MacLean D, Jikumaru Y, Hill L, Yamaguchi S, Kamiya Y, et al. The microRNA miR393 re-directs secondary metabolite biosynthesis away from camalexin and towards glucosinolates. Plant J 2011;67:218-31.

[42] Baldrich P, Campo S, Wu MT, Liu TT, Hsing YI, San Segundo B. MicroRNA-mediated regulation of gene expression in the response of rice plants to fungal elicitors. RNA Biol 2015;12:847-63.

[43] Campo S, Peris-Peris C, Sire C, Moreno AB, Donaire L, Zytnicki M, et al. Identification of a novel microRNA (miRNA) from rice that targets an alternatively spliced transcript of the Nramp6 (Natural resistance-associated macrophage protein 6) gene involved in pathogen resistance. New Phytol 2013;199:212-27.

[44] Li Y, Lu YG, Shi Y, Wu L, Xu YJ, Huang F, et al. Multiple rice microRNAs are involved in immunity against the blast fungus Magnaporthe oryzae. Plant Physiol 2014;164:1077-92.

[45] Chen M, Cao Z. Genome-wide expression profiling of microRNAs in poplar upon infection with the foliar rust fungus Melampsora larici-populina. BMC Genomics 2015;16:1-13.

[46] Kulcheski FR, de Oliveira LF, Molina LG, Almerao MP, Rodrigues FA, Marcolino J, et al. Identification of novel soybean microRNAs involved in abiotic and biotic stresses. BMC Genomics 2011;12:307-23.

[47] Gupta OP, Permar V, Koundal V, Singh UD, Praveen S. MicroRNA regulated defense responses in Triticum aestivum L. during Puccinia graminis f.sp. tritici infection. Mol Biol Rep 2012;39:817-24.

[48] Feng H, Duan X, Zhang Q, Li X, Wang B, Huang L, et al. The target gene of tae-miR164, a novel NAC transcription factor from the NAM subfamily, negatively regulates resistance of wheat to stripe rust. Mol Plant Pathol 2014;15:284-96.

[49] Feng H, Wang B, Zhang Q, Fu Y, Huang L, Wang X, et al. Exploration of microRNAs and their targets engaging in the resistance interaction between wheat and stripe rust. Front Plant Sci 2015;6:469-80. [50] Feng H, Wang T, Feng C, Zhang Q, Zhang X, Huang L, et al. Identification of microRNAs and their corresponding targets involved in the susceptibility interaction of wheat response to Puccinia striiformis $f$. sp. tritici. Physiol Plant 2015.

[51] Feng $\mathrm{H}$, Zhang $\mathrm{Q}$, Li H, Wang X, Wang X, Duan X, et al. vsiRNAs derived from the miRNAgenerating sites of pri-tae-miR159a based on the BSMV system play positive roles in the wheat response to Puccinia striiformis $f$. sp. tritici through the regulation of taMyb3 expression. Plant Physiol Biochem 2013;68:90-5.

[52] Feng $\mathrm{H}$, Zhang Q, Wang Q, Wang X, Liu J, Li M, et al. Target of tae-miR408, a chemocyanin-like protein gene ( $T a C L P 1)$, plays positive roles in wheat response to high-salinity, heavy cupric stress and stripe rust. Plant Mol Biol 2013;83:433-43.

[53] Yang L, Jue D, Li W, Zhang R, Chen M, Yang Q. Identification of MiRNA from eggplant (Solanum melongena $L$.) by small RNA deep sequencing and their response to Verticillium dahliae infection. PLoS One 2013;8:e72840.

[54] Yin Z, Li Y, Han X, Shen F. Genome-wide profiling of miRNAs and other small non-coding RNAs in the Verticillium dahliae-inoculated cotton roots. PLoS One 2012;7:e35765.

[55] Luan Y, Cui J, Zhai J, Li J, Han L, Meng J. High-throughput sequencing reveals differential expression of miRNAs in tomato inoculated with Phytophthora infestans. Planta 2015;241:1405-16. [56] Guo N, Ye WW, Wu XL, Shen DY, Wang YC, Xing H, et al. Microarray profiling reveals microRNAs involving soybean resistance to Phytophthora sojae. Genome 2011;54:954-8. 
[57] Wong J, Gao L, Yang Y, Zhai J, Arikit S, Yu Y, et al. Roles of small RNAs in soybean defense against Phytophthora sojae infection. Plant J 2014;79:928-40.

[58] Zhao M, Cai C, Zhai J, Lin F, Li L, Shreve J, et al. Coordination of microRNAs, phasiRNAs, and NB$L R R$ genes in response to a plant pathogen: Insights from analyses of a set of soybean Rps gene nearisogenic lines. Plant Genome 2015;8.

[59] Jin W, Wu F. Identification and characterization of cucumber microRNAs in response to Pseudoperonospora cubensis infection. Gene 2015;569:225-32.

[60] Verma SS, Rahman MH, Deyholos MK, Basu U, Kav NN. Differential expression of miRNAs in Brassica napus root following infection with Plasmodiophora brassicae. PLoS One 2014;9:e86648. [61] Curaba J, Singh MB, Bhalla PL. miRNAs in the crosstalk between phytohormone signaling pathways. J Exp Bot 2014;65:1425-38.

[62] Navarro L, Dunoyer P, Jay F, Arnold B, Dharmasiri N, Estelle M, et al. A plant miRNA contributes to antibacterial resistance by repressing auxin signaling. Science 2006;312:436-9.

[63] Guo HS, Xie Q, Fei JF, Chua NH. MicroRNA directs mRNA cleavage of the transcription factor NAC1 to downregulate auxin signals for Arabidopsis lateral root development. Plant Cell 2005;17:1376-86.

[64] Zhai J, Jeong D-H, De Paoli E, Park S, Rosen BD, Li Y, et al. MicroRNAs as master regulators of the plant $N B$ - $L R R$ defense gene family via the production of phased, trans-acting siRNAs. Genes Dev 2011;25:2540-53.

[65] O'Brien JA, Daudi A, Butt VS, Bolwell GP. Reactive oxygen species and their role in plant defence and cell wall metabolism. Planta 2012;236:3:765-79.

[66] Le T-N, Schumann U, Smith NA, Tiwari S, Au P, Zhu Q-H, et al. DNA demethylases target promoter transposable elements to positively regulate stress responsive genes in Arabidopsis. Genome Biol 2014;15:10.1186-203.

[67] Fei Q, Zhang Y, Xia R, Meyers BC. Small RNAs Add Zing to the Zig-Zag-Zig Model of Plant Defenses. MPMI 2016;09.

[68] Fei Q, Xia R, Meyers BC. Phased, secondary, small interfering RNAs in posttranscriptional regulatory networks. Plant Cell 2013;25:2400-15.

[69] Eitas TK, Dangl JL. NB-LRR proteins: pairs, pieces, perception, partners, and pathways. Curr Opin Plant Biol 2010;13:472-7.

[70] Li F, Pignatta D, Bendix C, Brunkard JO, Cohn MM, Tung J, et al. MicroRNA regulation of plant innate immune receptors. Proc Natl Acad Sci USA 2012;109:1790-5.

[71] Park JH, Shin C. The role of plant small RNAs in NB-LRR regulation. Brief Funct Genomics 2015;14:268-74.

[72] Shivaprasad PV, Chen H-M, Patel K, Bond DM, Santos BACM, Baulcombe DC. A microRNA superfamily regulates nucleotide binding site-leucine-rich repeats and other mRNAs. Plant Cell 2012;24:859-74.

[73] Zhu Q-H, Fan L, Liu Y, Xu H, Llewellyn D, Wilson I. miR482 regulation of NBS-LRR defense genes during fungal pathogen infection in cotton. PLoS One 2013;8:e84390.

[74] Liu J, Cheng X, Liu D, Xu W, Wise R, Shen Q-H. The miR9863 family regulates distinct Mla alleles in barley to attenuate NLR receptor-triggered disease resistance and cell-death signaling. PLoS Genet 2014;10:e1004755.

[75] Xia R, Meyers BC, Liu Z, Beers EP, Ye S, Liu Z. MicroRNA superfamilies descended from miR390 and their roles in secondary small interfering RNA biogenesis in eudicots. Plant Cell 2013;25:1555-72.

[76] Schwarzländer M, Finkemeier I. Mitochondrial energy and redox signaling in plants. Antioxid Redox Signal 2013;18:2122-44.

[77] Caplan JL, Kumar AS, Park E, Padmanabhan MS, Hoban K, Modla S, et al. Chloroplast stromules function during innate immunity. Dev cell 2015;34:45-57.

[78] Yan J, Gu Y, Jia X, Kang W, Pan S, Tang X, et al. Effective small RNA destruction by the expression of a short tandem target mimic in Arabidopsis. Plant Cell 2012;24:415-27. 
Table 1. Pathogen-responsive miRNAs that may indirectly influence immunity.

\begin{tabular}{|c|c|c|c|c|c|}
\hline miRNA & Pathosystem & & Target transcript & Function & Ref. \\
\hline $\operatorname{miR} 156$ & $\begin{array}{l}\text { Rice- } M . \text { oryzae } \\
\text { Soybean }-F \text {. virguliforme } \\
\text { Tomato }-F \text {. oxysprorum } \\
\text { Oilseed rape- } P \text {. brassicae } \\
\text { Poplar }-B \text {. dothidea }\end{array}$ & $\begin{array}{l}\text { Wheat-B. graminis } \\
\text { Soybean-P. sojae } \\
\text { Arabidopsis-F. oxysprorum } \\
\text { Pine-C. quercuum } \\
\text { Poplar-D. gregaria }\end{array}$ & $\begin{array}{l}\text { Squamosa promoter binding protein-like } \\
\text { (SPL) family TF }\end{array}$ & Plant growth and development & $\begin{array}{l}{[24,34-39,} \\
43,56,60, \\
79]\end{array}$ \\
\hline $\operatorname{miR} 157$ & Soybean $-P$. sojae & Tomato-F. oxysprorum & $\begin{array}{l}\text { Squamosa promoter binding protein-like } \\
\text { (SPL) family } \mathrm{TF}\end{array}$ & Plant growth and development & {$[39,56]$} \\
\hline miR159 & $\begin{array}{l}\text { Rice- } M . \text { oryzae } \\
\text { Wheat }-B \text {. graminis } \\
\text { Wheat }-P \text {. striiformis } \\
\text { Soybean }-P \text {. sojae } \\
\text { Pine- }- \text {. quercuum }\end{array}$ & $\begin{array}{l}\text { Wheat }-F \text {. culmorum } \\
\text { Wheat }-P \text {. graminis } \\
\text { Cucumber-P. cubensis } \\
\text { Tomato- } P \text {. infestans } \\
\text { Poplar- } B \text {. dothidea }\end{array}$ & $\begin{array}{l}\text { Myeloblastic leukemia (MYB) famiy TF } \\
\text { Cytokinin oxidase (CKX) family }\end{array}$ & $\begin{array}{l}\text { ABA/GA signaling, plant growth } \\
\text { and development } \\
\text { Cytokinin biogenesis, metabolism }\end{array}$ & $\begin{array}{l}{[33-35,43} \\
47,51,56 \\
79-81]\end{array}$ \\
\hline $\operatorname{miR} 160$ & $\begin{array}{l}\text { Rice }-M . \text { oryzae } \\
\text { Oilseed rape- } P \text {. brassicae } \\
\text { Cotton- } F \text {. oxysprorum } \\
\text { Poplar-B. dothidea }\end{array}$ & $\begin{array}{l}\text { Cucumber }-P . \text { cubensis } \\
\text { Oilseed rape }-V . \text { longisporum } \\
\text { Pine-C. quercuum }\end{array}$ & Auxin response factor (ARF) & Auxin signaling & $\begin{array}{l}{[25,35,43} \\
44,60,79 \\
80,82]\end{array}$ \\
\hline $\operatorname{miR} 162$ & $\begin{array}{l}\text { Rice }-M \text {. oryzae } \\
\text { Poplar-D. gregaria }\end{array}$ & Tomato $-F$. oxysprorum & Dicer-like protein 1 (DCL1) & Small RNA pathway & {$[24,39,42]$} \\
\hline $\operatorname{miR} 164$ & $\begin{array}{l}\text { Rice }-M \text {. oryzae } \\
\text { Wheat }-P \text {. graminis } \\
\text { Cucumber-P. cubensis } \\
\text { Tomato- } P \text {. infestans } \\
\text { Poplar }-B \text {. dothidea }\end{array}$ & $\begin{array}{l}\text { Wheat }-B . \text { graminis } \\
\text { Wheat }-P \text {. striiformis } \\
\text { Arabidopsis }-F . \text { oxysprorum } \\
\text { Oilseed rape- }- \text {. longisporum } \\
\text { Poplar-D. gregaria }\end{array}$ & NAM/ATAF/CUC (NAC) TF & $\begin{array}{l}\text { Auxin signaling, plant development, } \\
\text { nutrient homeostasis }\end{array}$ & $\begin{array}{l}{[25,34-36} \\
38,43,44 \\
48,80,81]\end{array}$ \\
\hline $\operatorname{miR} 166$ & $\begin{array}{l}\text { Rice }-M . \text { oryzae } \\
\text { Soybean }-P . \text { pachyrhizi } \\
\text { Tomato }-F . \text { oxysprorum } \\
\text { Oilseed rape }-P \text {. brassicae }\end{array}$ & $\begin{array}{l}\text { Wheat }-B . \text { graminis } \\
\text { Soybean-P. sojae } \\
\text { Arabidopsis-F. oxysprorum } \\
\text { Poplar-B. dothidea }\end{array}$ & $\begin{array}{l}\text { Class III homeodomain-leucine zipper } \\
\text { (HD-ZIPIII) family TF }\end{array}$ & $\begin{array}{l}\text { Root growth, lateral organ polarity, } \\
\text { meristem formation, vascular } \\
\text { development, abiotic and biotic } \\
\text { stress response }\end{array}$ & $\begin{array}{l}{[24,34,35} \\
38,39,43 \\
46,56,57 \\
60]\end{array}$ \\
\hline miR167 & $\begin{array}{l}\text { Rice }-M . \text { oryzae } \\
\text { Tomato }-F \text {. oxysprorum } \\
\text { Wheat }-P \text {. graminis }\end{array}$ & $\begin{array}{l}\text { Oilseed rape }-V . \text { longisporum } \\
\text { Arabidopsis }-F . \text { oxysprorum }\end{array}$ & Auxin response factor (ARF) & Auxin signaling & $\begin{array}{l}{[24,25,38,} \\
39,43,44, \\
47]\end{array}$ \\
\hline $\operatorname{miR} 168$ & $\begin{array}{l}\text { Rice }-M . \text { oryzae } \\
\text { Soybean }-P . \text { sojae } \\
\text { Poplar-B. dothidea }\end{array}$ & $\begin{array}{l}\text { Arabidopsis }-F . \text { oxysprorum } \\
\text { Oilseed rape- }-V . \text { longisporum } \\
\text { Poplar-D. gregaria }\end{array}$ & Argonaute protein 1 (AGO1) & $\begin{array}{l}\text { Small RNA pathway, abiotic and } \\
\text { biotic stress response }\end{array}$ & $\begin{array}{l}{[24,25,35} \\
36,38,42- \\
44,57]\end{array}$ \\
\hline $\operatorname{miR} 169$ & $\begin{array}{l}\text { Rice }-M \text {. oryzae } \\
\text { Wheat-B. sorokiniana } \\
\text { Oilseed rape- } P \text {. brassicae } \\
\text { Poplar-D. gregaria }\end{array}$ & $\begin{array}{l}\text { Wheat }-F \text {. culmorum } \\
\text { Soybean-P. pachyrhizi } \\
\text { Oilseed rape- }-V . \text { longisporum } \\
\text { Arabidopsis }-F . \text { oxysprorum }\end{array}$ & $\begin{array}{l}\text { Nuclear Factor Y subunit A (NFYA) } \\
\text { family TF }\end{array}$ & $\begin{array}{l}\text { Plant growth and development, } \\
\text { stomata closure, basal defense, } \\
\text { abiotic and biotic stress response }\end{array}$ & $\begin{array}{l}{[24,25,33} \\
36,38,43 \\
44,46,60]\end{array}$ \\
\hline $\operatorname{miR} 171$ & $\begin{array}{l}\text { Rice }-M . \text { oryzae } \\
\text { Wheat }-B . \text { graminis } \\
\text { Cucumber }-P \text {. cubensis }\end{array}$ & $\begin{array}{l}\text { Wheat }-F \text {. culmorum } \\
\text { Wheat }-P \text {. graminis } \\
\text { Soybean }-P \text {. sojae }\end{array}$ & Scarecrow-like protein (SCL) family TF & $\begin{array}{l}\text { GA-DELLA signaling, floral } \\
\text { patterning, leaf growth, chlorophyll } \\
\text { biosynthesis, stress response }\end{array}$ & $\begin{array}{l}{[33,34,43,} \\
47]\end{array}$ \\
\hline $\operatorname{miR} 172$ & $\begin{array}{l}\text { Rice-M. oryzae } \\
\text { Poplar }-B . \text { dothidea }\end{array}$ & $\begin{array}{l}\text { Arabidopsis }-F . \text { oxysprorum } \\
\text { Oilseed rape }-P \text {. brassicae }\end{array}$ & $\begin{array}{l}\text { APETALA2(AP2)-like TF } \\
\text { Target of eat (TOE) TF }\end{array}$ & $\begin{array}{l}\text { Flower development, abiotic and } \\
\text { biotic stress response }\end{array}$ & {$[56,80]$} \\
\hline $\operatorname{miR} 319$ & $\begin{array}{l}\text { Wheat }-B \text {. sorokiniana } \\
\text { Soybean-P. sojae } \\
\text { Poplar-B. dothidea }\end{array}$ & $\begin{array}{l}\text { Oilseed rape- }-V . \text { longisporum } \\
\text { Pine-C. quercuum }\end{array}$ & $\begin{array}{l}\text { Teosinte branched } 1 \text {-Cycloidea-PCF } \\
\text { (TCP) family TF }\end{array}$ & $\begin{array}{l}\text { Flower development, abiotic and } \\
\text { biotic stress response }\end{array}$ & $\begin{array}{l}{[25,33,56,} \\
57]\end{array}$ \\
\hline $\operatorname{miR} 390$ & Rice-M. oryzae & Oilseed rape- $V$. longisporum & TAS3 & Auxin signaling & {$[25,43]$} \\
\hline $\operatorname{miR} 393$ & $\begin{array}{l}\text { Rice }-M . \text { oryzae } \\
\text { Eggplant }-V . \text { dahliae } \\
\text { Soybean }-P . \text { sojae }\end{array}$ & $\begin{array}{l}\text { Wheat }-B . \text { graminis } \\
\text { Arabidopsis }-H \text {. arabidopsidis } \\
\text { Poplar-D. gregaria }\end{array}$ & $\begin{array}{l}\text { Transport inhibitor response 1/Auxin- } \\
\text { related F-box (TIR/AFB) } \\
\text { Suppressor of gene silencing } 3 \text { (SGS3) }\end{array}$ & Auxin signaling & $\begin{array}{l}{[34,36,41-} \\
43,53,57]\end{array}$ \\
\hline $\operatorname{miR} 394$ & $\begin{array}{l}\text { Rice-M. oryzae } \\
\text { Poplar-M. larici-populina }\end{array}$ & Tomato-F. oxysprorum & F-box protein & $\begin{array}{l}\text { Plant growth and development, leaf } \\
\text { morphology }\end{array}$ & {$[39,43,45]$} \\
\hline $\operatorname{miR} 396$ & $\begin{array}{l}\text { Rice }-M \text {. oryzae } \\
\text { Tomato }-F \text {. oxysprorum } \\
\text { Oilseed rape- } P \text {. brassicae }\end{array}$ & $\begin{array}{l}\text { Wheat }-B \text {. graminis } \\
\text { Soybean }-P \text {. sojae }\end{array}$ & $\begin{array}{l}\text { Growth-regulating factor (GRF) } \\
\text { Basic helix-loop-helix (bHLH) TF } \\
\text { WRKY6 TF }\end{array}$ & $\begin{array}{l}\text { Cell proliferation } \\
\text { Flower development } \\
\text { Abiotic and biotic stress response }\end{array}$ & $\begin{array}{l}{[24,34,39} \\
43,44,56 \\
60]\end{array}$ \\
\hline $\operatorname{miR} 399$ & Eggplant-V. dahliae & & $\begin{array}{l}\text { Phosphate } 2 \text { (PHO2), a ubiquitin- } \\
\text { conjugating E2 enzyme }\end{array}$ & $\begin{array}{l}\text { Phosphorus deficiency signaling, } \\
\text { flower development }\end{array}$ & {$[53]$} \\
\hline $\operatorname{miR} 403$ & Tomato-F. oxysprorum & Soybean-P. sojae & $\begin{array}{l}\text { Argonaute protein } 2 \text { and } 3 \text { (AGO2 and } \\
\text { AGO3) }\end{array}$ & Small RNA pathways & {$[39,56]$} \\
\hline $\operatorname{miR} 444$ & $\begin{array}{l}\text { Rice }-M . \text { oryzae } \\
\text { Wheat }-P \text {. graminis }\end{array}$ & Wheat $-B$. graminis & MADS-box TF & $\begin{array}{l}\text { Flower development, hormone } \\
\text { signaling }\end{array}$ & {$[34,43,47]$} \\
\hline $\operatorname{miR} 823$ & Arabidopsis $-F$. oxysprorum & & Chromomethylase 3 (CMT3) & RNA-directed DNA methylation & [38] \\
\hline $\operatorname{miR} 827$ & Rice $-M$. oryzae & Wheat $-B$. graminis & $\begin{array}{l}\text { SYG1/Pho81/XPR1 (SPX) domain } \\
\text { containing protein }\end{array}$ & Phosphorus deficiency signaling & {$[34,43,44]$} \\
\hline $\operatorname{miR} 1136$ & Wheat $-P$. striiformis & & Zinc finger protein & $\begin{array}{l}\text { DNA/protein/lipid binding, RNA } \\
\text { packaging, apoptosis }\end{array}$ & [49] \\
\hline $\operatorname{miR} 1138$ & Wheat $-P$. graminis & Wheat $-P$. striiformis & Elongation factor $4 \mathrm{~b}(\mathrm{eIF}-4 \mathrm{~b})$ & Protein synthesis & {$[47,50]$} \\
\hline $\operatorname{miR} 1432$ & Wheat $-P$. striiformis & & Calcium ion-binding protein & Calcium signaling & {$[50]$} \\
\hline $\operatorname{miR} 1847$ & Rice-M. oryzae & Wheat $-P$. striiformis & Argonaute protein 4 (AGO4) & Small RNA pathway & {$[42,50]$} \\
\hline $\operatorname{miR} 1850$ & Rice-M. oryzae & & RNA-dependent RNA polymerase 2 & Small RNA pathway & {$[42,43]$} \\
\hline $\operatorname{miR7695}$ & Rice $-M$. oryzae & & $\begin{array}{l}\text { Natural resistance-associated } \\
\text { macrophage protein } 6 \text { (NRAMP6) }\end{array}$ & Metal transportation & {$[43]$} \\
\hline PC-490 & Wheat $-P$. striiformis & & $\begin{array}{l}\text { TBC domain containing protein, a } \\
\text { RabGTPases activating protein }\end{array}$ & Endomembrane system trafficking & [49] \\
\hline PC-7484 & Wheat $-P$. striiformis & & Ubiquilin, an ubiquitin-like protein & Protein degradation & {$[50]$} \\
\hline
\end{tabular}


Table 2. Pathogen-responsive miRNAs directly regulating defense-related genes.

\begin{tabular}{|c|c|c|c|c|c|}
\hline miRNA & Pathosystem & & Predicted target transcript & Function & Ref. \\
\hline miR156 & Pine-C. quercuum & & NB-LRR protein family & Defense response & {$[32]$} \\
\hline $\operatorname{miR} 159$ & Poplar-B. dothidea & & Peroxidase & Oxidative stress & [35] \\
\hline $\operatorname{miR} 164$ & Poplar-B. dothidea & & Leucine-rich repeat protein family & Defense response & [35] \\
\hline $\operatorname{miR} 390$ & Rice-M. oryzae & Oilseed rape $-V$. longisporum & Leucine-rich repeat protein family & Defense response & {$[25,43]$} \\
\hline $\operatorname{miR} 396$ & $\begin{array}{l}\text { Rice- } M . \text { oryzae } \\
\text { Tomato }-F . \text { oxysporum }\end{array}$ & $\begin{array}{l}\text { Wheat }-B . \text { graminis } \\
\text { Soybean }-P . \text { sojae }\end{array}$ & WRKY TF & Abiotic and biotic stress response & $\begin{array}{l}{[24,34,39,} \\
43,44,56, \\
60]\end{array}$ \\
\hline $\operatorname{miR} 397$ & $\begin{array}{l}\text { Soybean }-F \text {. virguliforme } \\
\text { Poplar-M. larici-populina }\end{array}$ & Soybean $-P$. pachyrhizi & Laccase copper protein family & Lignin formation & {$[37,45,46]$} \\
\hline $\operatorname{miR} 398$ & $\begin{array}{l}\text { Rice }-M . \text { oryzae } \\
\text { Tomato }-F \text {. oxysporum }\end{array}$ & $\begin{array}{l}\text { Wheat-B. sorokiniana } \\
\text { Poplar-B. dothidea }\end{array}$ & Copper/zinc superoxide dismutase (CSD) & $\begin{array}{l}\text { Oxidative stress detoxification, } \\
\text { abiotic and biotic stress response }\end{array}$ & $\begin{array}{l}{[33,35,39,} \\
42,44]\end{array}$ \\
\hline $\operatorname{miR} 408$ & $\begin{array}{l}\text { Wheat }-P . \text { graminis } \\
\text { Poplar- } B . \text { dothidea }\end{array}$ & Wheat- $P$. striiformis & $\begin{array}{l}\text { Plantacyanin-like copper protein family } \\
\text { Laccase copper protein family }\end{array}$ & $\begin{array}{l}\text { Programmed cell death, lignin } \\
\text { formation }\end{array}$ & {$[35,47,52]$} \\
\hline $\operatorname{miR} 482 *$ & $\begin{array}{l}\text { Wheat }-F . \text { culmorum } \\
\text { Soybean-P. pachyrhizi } \\
\text { Poplar-D. gregaria } \\
\text { Cotton-V. dahliae }\end{array}$ & $\begin{array}{l}\text { Tomato-F. oxysporum } \\
\text { Soybean-P. sojae } \\
\text { Poplar-M. larici-populina }\end{array}$ & NB-LRR protein family & Defense response & $\begin{array}{l}{[33,39,45,} \\
46,56,58]\end{array}$ \\
\hline $\operatorname{miR} 528$ & Rice $-M$. oryzae & & $\begin{array}{l}\text { Ascorbate oxidase } \\
\text { Laccase copper protein family }\end{array}$ & Oxidative stress, lignin formation & {$[42,43]$} \\
\hline $\operatorname{miR} 827$ & Rice-M. oryzae & & Wall-associated receptor-like kinase (WAK) & $\begin{array}{l}\text { Cell expansion, pathogen resistance, } \\
\text { metal tolerance }\end{array}$ & {$[34,43,44]$} \\
\hline $\operatorname{miR} 869$ & Wheat $-B$. sorokiniana & Wheat $-F$. culmorum & Glucuronosyltransferase & Anti-mycotoxin defense & [33] \\
\hline $\operatorname{miR} 1448$ & Cotton-V. dahliae & Poplar-B. dothidea & NB-LRR protein family & Defense response & {$[35,54]$} \\
\hline $\operatorname{miR} 1507 *$ & Soybean-P. sojae & & NB-LRR protein family & Defense response & {$[56,57]$} \\
\hline miR1510* & Soybean-P. sojae & & $\begin{array}{l}\text { NB-LRR protein family } \\
\text { Short-chain dehydrogenases/reductase }\end{array}$ & $\begin{array}{l}\text { Defense response } \\
\text { Metabolism }\end{array}$ & {$[56,58]$} \\
\hline $\operatorname{miR} 1524 *$ & Soybean-P. sojae & & NB-LRR protein family & Defense response & {$[58]$} \\
\hline miR1536* & Soybean-P. sojae & & NB-LRR protein family & Defense response & [58] \\
\hline $\operatorname{miR} 2109 *$ & Soybean-P. sojae & & NB-LRR protein family & Defense response & {$[57,58]$} \\
\hline $\operatorname{miR} 2118 *$ & $\begin{array}{l}\text { Cotton- } V . \text { dahliae } \\
\text { Soybean- } P . \text { sojae }\end{array}$ & Poplar-M. larici-populina & NB-LRR protein family & Defense response & {$[45,58]$} \\
\hline miR5300* & Tomato- $F$. oxysporum & Tomato- $P$. infestans & NB-LRR protein family & Defense response & {$[39,55]$} \\
\hline $\operatorname{miR} 9863 *$ & Barley-B. graminis & & NB-LRR protein family & Defense response & [74] \\
\hline PC-162 & Wheat $-P$. striiformis & & Cysteine-rich receptor-like protein kinase 41 & Pathogen perception & [49] \\
\hline
\end{tabular}

* represents miRNAs that can trigger the production of secondary siRNAs 
Figure 1. Biogenesis of miRNA and phasiRNA in plants. (A) miRNA biogenesis pathway. The primary transcripts of miRNAs (pri-miRNAs) are transcribed by RNA Polymerase II from endogenous MIR loci. pri-miRNAs are processed by the DCL1 complex in a two-step process; and the resulting doublestranded miRNA duplexes are subsequently stabilized by HEN1-mediated methylation. One miRNA strand is loaded into the AGO-containing RNA-induced silencing complex to suppress gene expression. (B) Rather than directly binding to target mRNAs, some miRNAs trigger secondary siRNA production. These siRNAs are often in 21-nt regime, therefore, they are also called phased siRNAs or phasiRNAs. The transcripts of PHAS or TAS loci are cleaved by AGO/miRNA complex and used to synthesize long double-stranded RNAs (dsRNAs) by RDR6 and SGS3. phasiRNAs are then generated from the long dsRNAs by DCL4 and subsequently loaded into AGO-containing RNA-induced silencing complex to induce target gene silencing.

\section{Figure 2. A schematic overview of miRNA regulations in response to filamentous pathogens.}

Transcriptional regulation of MIR genes leads to differential accumulation of specific miRNAs upon pathogen infection. These pathogen-responsive miRNAs influence cellular processes including phytohormone signaling, defense response and RNA silencing. For example, miR168 and miR162 often show altered expression during filamentous pathogen infection, suggesting the pathogenresponsive miRNA pathway might be fine-tuned by a negative feedback regulation through the repression of miR168 and miR162 on AGO1 and DCL1, respectively. In addition, many pathogenresponsive miRNAs are predicted to target transcription factors, which might, in turn, regulate MIR gene expression. Although experimental data are lacking, promoter analysis on pathogen-responsive MIR loci reveals the presence of phytohormone- and stress-responsive regulatory elements. These elements may associate with specific transcription factors that may or may not be targets of miRNAs. 
A

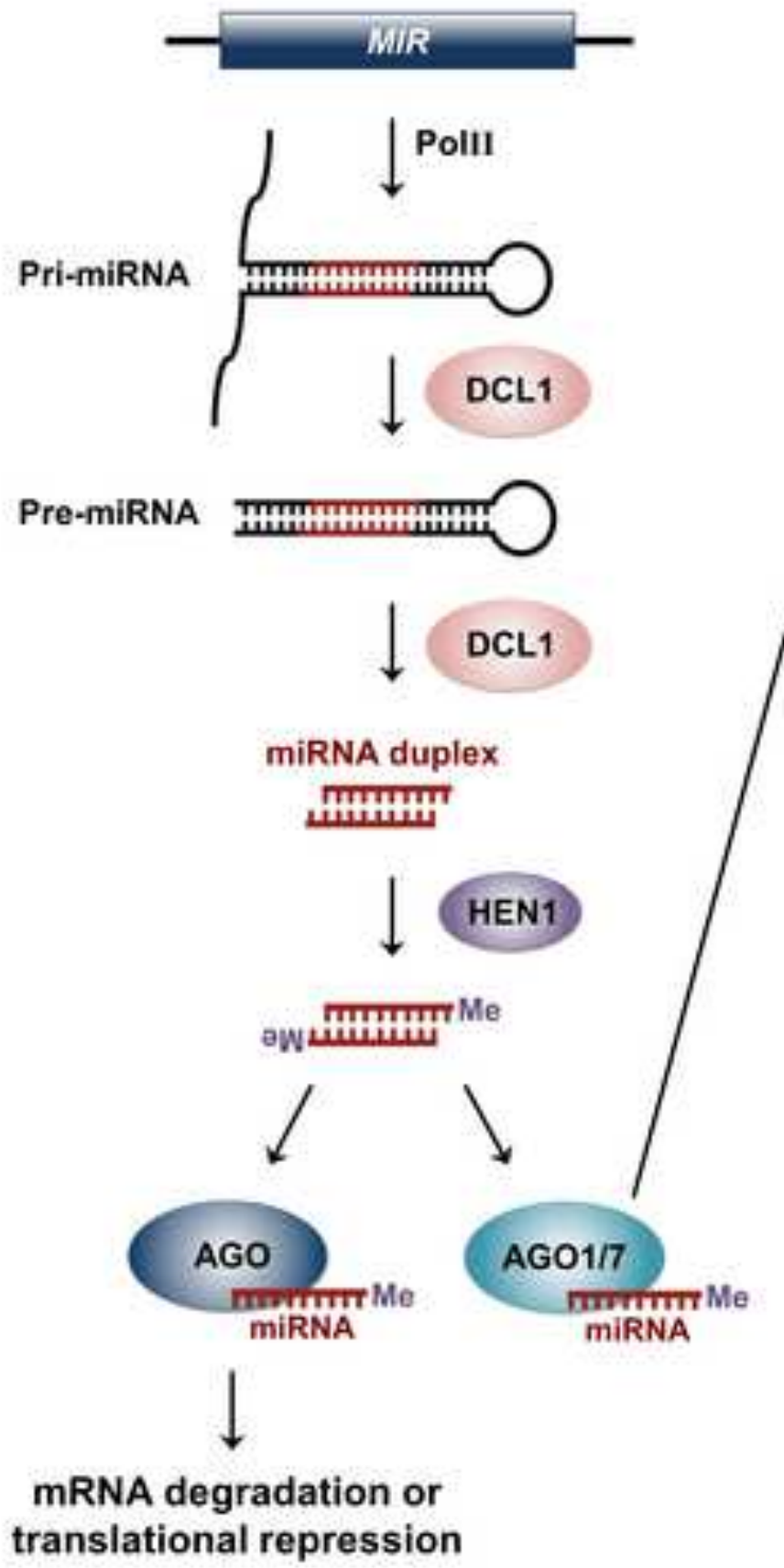

B

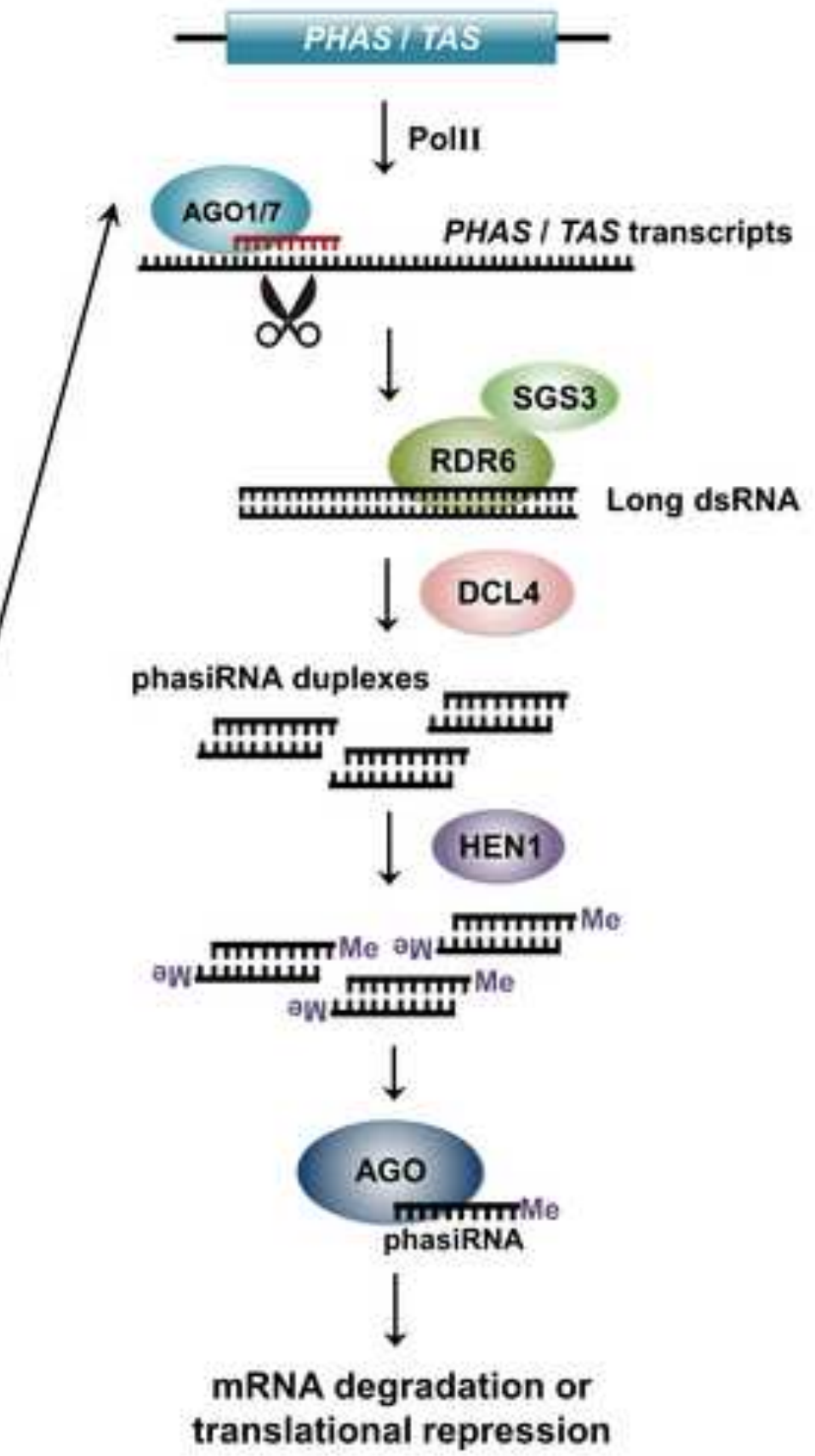




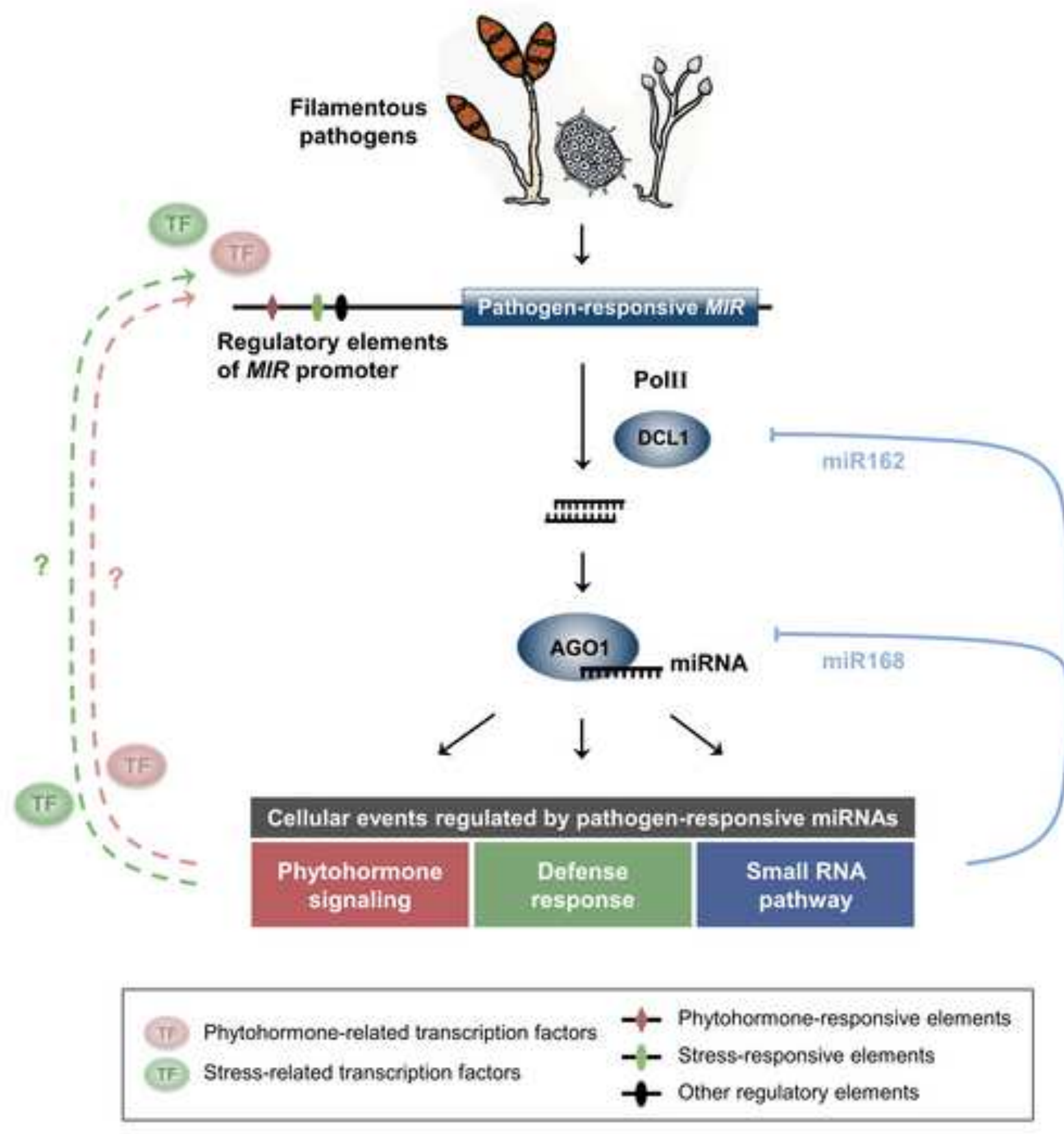

\section{Regulatory elements \\ of MIR promoter}

Cellular events regulated by pathogen-responsive miRNAS

Defense
response

Small RNA pathway

Phytohormone-related transcription factors - - Stress-responsive elements Other regulatory elements

Stress-related transcription factors 